\title{
Effectiveness and acceptability of milled rumble strips on rural two-lane roads in Sweden
}

\author{
Anna Vadeby ${ }^{1}$ (D) Anna Anund ${ }^{1,2}$
}

Received: 15 April 2016/Accepted: 9 May 2017 /Published online: 18 May 2017

(C) The Author(s) 2017. This article is an open access publication

\begin{abstract}
Purpose The study sought to estimate the effects of centreline milled rumble strips on rural two-lane roads in Sweden in a wide perspective. Traffic safety effects (i.e., fewer crashes and injuries), driver experience, and driver opinions of centreline milled rumble strip usage on rural roads are investigated.

Methods To evaluate the traffic safety effects, an Empirical Bayes study comparing the outcome before and-after the introduction of rumble strips was conducted. This study is based on data from 2003-2012 from the Swedish national traffic accident database, STRADA. To capture driver experience and opinions about milled centreline rumble strips, focus groups and road-side interviews were performed.

Results The results indicate a significant decrease in all types of severe injury crashes, a $20 \%( \pm 13 \%)$ reduction in the number of fatalities and seriously injured people (all crash types) and a $27 \%( \pm 18 \%)$ reduction in the number of fatalities and severely injured people in single-vehicle crashes. Participants in focus groups and road-side interviews generally favoured centreline rumble strips on rural roads, and up to $90 \%$ of the interviewed motorcyclists and commuters stated that the rumble strips would help improve traffic safety.

Conclusions Rumble strips in the centre of two-lane rural roads are a countermeasure to help drivers who are unintentionally about to leave the lane, for example, due to sleepiness or inattention. Based on the results of this study, installing
\end{abstract}

Anna Vadeby

anna.vadeby@vti.se

1 The Swedish National Road and Transport Research Institute, VTI, SE-581 95 Linköping, Sweden

2 Rehabilitation Medicine, Linköping University, SE-581 85 Linköping, Sweden centreline milled rumble strips on two-lane rural roads $8-10$ meters wide is a measure to consider to increase safety.

Keywords Milled rumble strips $\cdot$ Traffic safety $\cdot$ Driver acceptance $\cdot$ Focus groups: Road side interviews $\cdot$ Empirical Bayes

\section{Introduction}

Rumble strips in the centre of two-lane rural roads and on the shoulder of motorways are a countermeasure to help drivers who are unintentionally about to leave the lane, for example, due to sleepiness or inattention. Rumble strips have been used widely in several countries for a long time, especially in the USA and Canada [1]. Sometimes they are installed in raised profile and sometimes as in-ground, and the variation is not only between raised versus in-ground rumble strips but also in their width, depth, and length [1]. A report from the USA [2] establish that it is difficult to specify optimal dimensions of shoulder and centreline rumble strips due to lack of knowledge on e.g. the stimuli levels necessary to alert inattentive, distracted, drowsy, or fatigued drivers, but provides guidelines based on present knowledge. Evaluations of rumble strip effectiveness demonstrate that the rumble strips are useful not only for sleepy [3] but also for inattentive drivers [4, 5]. A before-after study in seven US states, including 98 treatment sites and over 210 miles of road, examining centre-line rumble strips found a reduction in injury crashes of approximately $15 \%$ (CI 5-25\%) and in frontal and opposing-direction sideswipe injury crashes of approximately $25 \%$ (CI 5 $45 \%)[6,7]$. The effect of rumble strips on the shoulder is even more positive $(40-50 \%)$ [8]. 
A quasi-experimental study of the Albany Highway in Western Australia resulted in a reduction in the all-severity crash rate of $58 \%$ and in casualty crashes of $80 \%$ [9]. The US report [2] concludes that centreline rumble strips reduce the total number of crashes by $9 \%(\mathrm{SE}=2)$ and the fatal and injury crashes by $12 \%(\mathrm{SE}=3)$. Looking at the target crashes only (defined as head-on and opposite-direction sideswipe crashes head on), the total number of target crashes are reduced by $30 \%(\mathrm{SE}=5)$ and the total number of fatal and injury crashes by $44 \%(\mathrm{SE}=6)$. There is also support for an adverse effect in terms of crash migration from locations with to those without rumble strips [10]. Most of these studies consider a mixture of raised and in-ground rumble strips, and also include variation in the type of in-ground strips. This heterogeneity is a confounding factor that is a limitation especially in estimating the optimal effect. A study from Norway including large-scale reports of real-world driver experience supports the evidence that rumble strips reduce crash numbers by reducing the severity of consequences, specifically of fatiguerelated driving, and found a significant reduction in sleepbehind-the-wheel incidents resulting in road departure crashes when rumble strips were present [11].

Simulator studies have demonstrated that milled rumble strips do not cause erratic manoeuvring when drivers are alert $[12,13]$ or sleepy [14]. A Finnish study of alert drivers demonstrated a decrease in the mean and standard deviation of lateral lane position due to less space to swerve before hitting the rumble strips [15]. These results are also supported by video observations from an equipped vehicle that indicated increased vehicle separation attributable to the rumble strips [16]. It is also know that hitting a milled rumble strip when sleepy effectively brings the driver back into the lane [14, 17]. The effect of hitting a rumble strip when sleepy is fairly short in duration (i.e., 3-4 min) and drivers will return to the same sleepiness level as just before hitting the rumble strip [14] What happens on real roads and whether the driver behaves differently depending on the reason for hitting the rumble strip (i.e., sleepiness vs. distraction) is unknown.

Unlike the many studies of rumble strip effectiveness, relatively few studies treat driver opinions and experience of rumble strips. Most studies do not consider the driver opinions and acceptance of the strips, a matter that merits further investigation.

An alternative solution to prevent single vehicle and head on crashes is lane departure warnings in terms of a driver support system, LDW systems. It has been shown that there is a potential to substitute the infrastructure rumble strip with an in-vehicle LDW system [18]. In an investigation of the safety benefits of in-vehicle LDW and LKA (Lane keeping Aid) in real world passenger car injury crashes in Sweden a positive effect in reducing single vehicle crashes $(-53 \%)$ as well as a total reduction of $-30 \%$ for all head-on and single vehicle driver injury crashes was shown [19].

\section{Objective}

This study evaluates the wider effects of centreline milled rumble strips on rural two-lane roads with a speed limit of $90 \mathrm{~km} / \mathrm{h}$. The evaluation considers traffic safety effects, driver experience, and driver opinions of milled rumble strips on Swedish rural roads.

\section{Methods}

In Sweden in the early 2000s, the Swedish Road Administration (now the Swedish Transport Administration) investigated the possibility of improving traffic safety and accessibility on existing rural roads by installing milled rumble strips in the centre of the road. After pilot studies in 2005 and 2006, a decision was made that all rural two-lane roads with a speed limit of $80 \mathrm{~km} / \mathrm{h}$ or above and wider than $7.5 \mathrm{~m}$ should have centreline milled rumble strips installed. As of the end of 2013, about $4700 \mathrm{~km}$ of rural roads in Sweden have centreline milled rumble strips with a total annual traffic volume of approximately 5.8 billion vehicle $\mathrm{km}$. Only about $5 \%$ of the roads are equipped with edge line rumble strips.

The centreline milled rumble strips are usually intermittent rumble strips $30-35 \mathrm{~cm}$ wide, $15 \mathrm{~cm}$ long, and $1 \mathrm{~cm}$ deep most often with a centre-to-centre distance of $60 \mathrm{~cm}$, Fig 1 . To prevent noise nuisance for those living near the road, caused by vehicles hitting the rumble strip, a buffer zone of $150 \mathrm{~m}$ is used. This means that for $20-30 \%$ of the length of roads with centreline milled rumble strips there is a break with no rumble strips.

\subsection{Evaluation of crashes}

Centreline rumble strips are expected to reduce the number of single-vehicle crashes and crashes with oncoming vehicles, thereby reducing the number of crashes, fatalities, and injuries. The traffic safety evaluation was based on crashes reported by the police in the Swedish national STRADA accident database (Swedish Traffic Accident Data Acquisition) for the 2003-2012 period. Crashes with pedestrians, bicycles, mopeds, track-based vehicles, and game were excluded from the analyses. In total, 180 sections of rural roads were included in the analysis. The crash outcome in the after period was compared with the outcome in the before period. Only road sections with both a before and after period and unchanged speed limit were included in the analysis. Since there are no rumble strips at junctions, crashes at junctions were excluded. In total, approximately $1850 \mathrm{~km}$ (annual traffic volume of 2.0 billion vehicle $\mathrm{km}$ ) of roads with a speed limit of $90 \mathrm{~km} / \mathrm{h}$ and road width under $10 \mathrm{~m}$ were included in the analysis.

Table 1 shows traffic volumes, number of injury crashes, and number of fatalities and severely injured (FSI) people in 


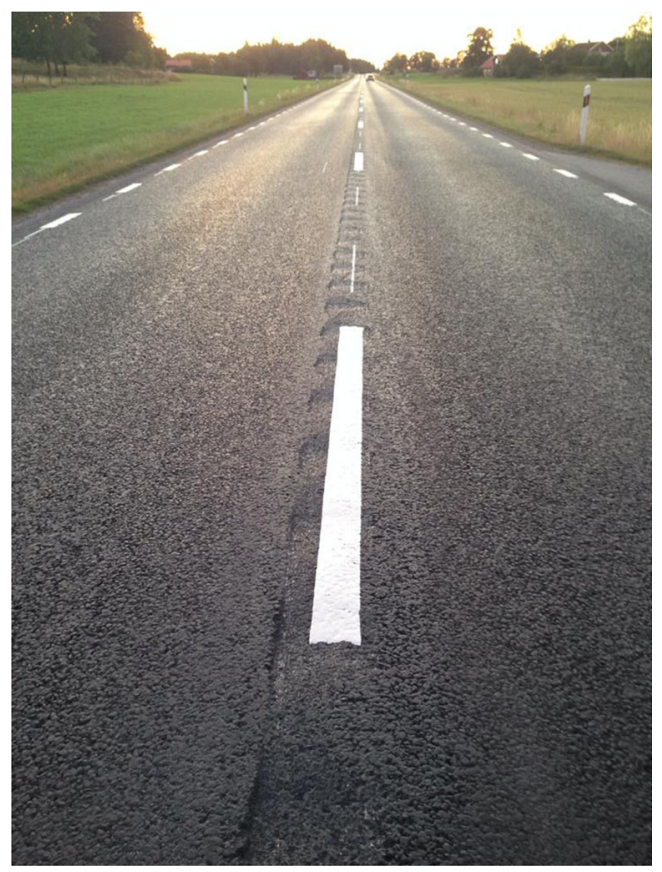

Fig. 1 Example of road with centreline milled rumble strips

the before and after periods. The traffic volumes were approximately 20\% higher in the before period compared with the after period, reflecting a longer duration of the before-period. For all crashes on the evaluated roads, there were 342 FSI in the before period and 216 in the after period, while there were 984 injury crashes before and 836 after.

To evaluate the traffic safety effects of milled centreline rumble strips on rural two-lane roads, the numbers of injury crashes and of people killed or severely injured before and after rumble strip installation were compared in a before and after Empirical Bayes (EB) study as well as a before-after study with a control group. The EB study controls for trend, traffic volume and regression to the mean, while the before and after study only controls for trend and traffic volumes.

In the before and after study with control, the change between the before and after periods is estimated as:

$\hat{\theta}=c k \frac{\sum Y}{\sum X}$

where $X$ is the number of observed crashes in the before period, and $\mathrm{Y}$ the number in the after period (summarized over all road sections), c corrects for differences in traffic volumes between the before and after period and $\mathrm{k}$ corrects for the changes in the control group. To estimate the trend $(\mathrm{k})$ in the control group, the number of injury crashes as well as the number of fatal and seriously injured (FSI) per year for an average before and after period were calculated. The index is calculated as the ratio between the after and before outcomes in the control group and is $1.047 \pm 0.038$ for personal injury accidents and $0.821 \pm 0.066$ for FSI $(95 \%$ confidence interval). The traffic safety effect is estimated by $\theta-1$. Following a first-order Taylor expansion [20], the variance is estimated by

$\operatorname{Var}(\hat{\theta})=\left[c k \frac{\sum Y}{\sum X}\right]^{2}\left(\frac{1}{\sum X}+\frac{1}{\sum Y}\right)$

and a $95 \%$ confidence interval is:

$$
C I=\hat{\theta} \pm 1,96^{*} \sqrt{\operatorname{Var}(\hat{\theta})} .
$$

To control for regression to the mean (RTM), an empirical Bayes (EB) approach were used. EB is the most common method of controlling for regression to the mean in before-after studies [21]. There are several versions of the EB approach [22, 23], which in the present case, briefly stated, relies on estimating the expected number of crashes by combining two sources of information: the recorded number of crashes and the normal expected number of crashes estimated by an accident prediction model. In principle, the normal expected number of crashes can be obtained from the empirical distribution of a control dataset. The data available for this evaluation do not contain a proper control dataset for estimating the normal expected number of crashes, but instead rely on an EB approach developed for and often used in Swedish traffic safety evaluations [24]. The expected number of crashes, $E(\alpha \mid r)$, is calculated as

$$
E(\alpha \mid r)=w \alpha+(1-w) r
$$

Table 1 Traffic volume, number of injury crashes, and the number of fatalities and severely injured (FSI) people in the before and after periods on the

\begin{tabular}{|c|c|c|c|c|c|c|c|}
\hline \multirow[t]{2}{*}{ Road type } & \multirow[t]{2}{*}{ Crash type } & \multicolumn{2}{|c|}{ Traffic volume (million axle-pair km) } & \multicolumn{2}{|c|}{ Number of injury crashes } & \multicolumn{2}{|c|}{ Number of FSI } \\
\hline & & Before & After & Before & After & Before & After \\
\hline \multirow[t]{2}{*}{ Rural roads, $90 \mathrm{~km} / \mathrm{h}$} & All & 10,610 & 8756 & 984 & 836 & 342 & 216 \\
\hline & Single vehicle & 10,610 & 8756 & 596 & 523 & 178 & 96 \\
\hline
\end{tabular}
studied rural centreline milled roads 
where $\alpha$ is the expected normal number of crashes, $r$ is the recorded number of crashes, and $\mathrm{w}$ is a weight, which is calculated as

$$
w=\frac{1}{1+k \alpha}
$$

The expected normal number of crashes, $\alpha$, is calculated from standard model values (i.e., estimated crash and FSI rates) based on the national average outcome over a fixed period for a certain road type and speed limit, and the weight, $w$, is estimated to be 0.1 for Swedish conditions [25]. The standard model values are based on the 2003-2008 period, which is the average before period (Table 1).

\subsection{Driver experience}

If rumble strips should be mandatory on 2 lane rural roads it is of major importance to gather the drivers experience and opinions. To do this both qualitative and quantitative studies were performed. The qualitative study was based on focus group discussions intended to capture motorcyclist and commuter experience and opinions of milled rumble strips on narrow rural roads.

The quantitative study was explorative and based on roadside interviews designed to capture the perceptions and experience of road users who had just travelled over roads with centreline milled rumble strips. The following section briefly describes the methods used.

\subsubsection{Focus groups}

Focus group discussions are a qualitative research method intended to obtain a wide-ranging description of how people reason about a specific topic or phenomenon [26, 27], in this case, centreline milled rumble strips on rural roads. Of the two stakeholder groups, i.e., motorcyclists and commuters, motorcyclists were selected assuming that they might find them less safe than drivers of passenger cars, possibly even cause endangering situations when crossing them during overtaking. Commuters were chosen based on the argument that these drivers are likely the most experienced ones, as they drive a lot and should therefore have more experience of driving on roads with milled rumble strips. Before implementing the focus groups, participants received written invitations that also contained information about the project. The discussions were relatively structured and followed an interview guide [28]. The discussions were voice recorded. The analysis was thematic note based and the voice recordings was used as a support to the notes.

The motorcyclist focus group comprised six motorcyclists, one woman and five men, 30-55 years old. They were recruited through personal contacts. They drove their own bikes representing the following brands: Kawasaki, BMW 1200, BMW 1100, Honda VFR 800, Varadeo 1000 and HD Sportser 1200. All were experienced motorcyclists who drove $3000-10,000 \mathrm{~km} / \mathrm{year}$. The discussion took part in August 2007 and lasted in total for approximately $3 \mathrm{~h}$. To ensure that the participating motorcyclists had experience of driving on centreline milled rumble strips and to facilitate productive discussion of rumble strips in a natural way, a group motorcycle trip on Highway 36/34 between Linköping and Borensberg, approximately $40 \mathrm{~km}$ apart, was performed before the discussion. The rumble strips applied on this part of the road is a typical solution in Sweden. The rumble strip has width of $30 \mathrm{~cm}$, a length of $15 \mathrm{~cm}$, a cc of $60 \mathrm{~cm}$ and a depth of $1.0 \mathrm{~cm}$. Some part of the road had $2+1$ fences.

Before the start an information meeting was done at VTIs premise. After the information, the riders were asked if they had questions and informed that they had they right to stop without reason at any time. The group then drove the $40 \mathrm{~km}$ together. The moderator and observer travelled as passengers. The participants were advised to cross the rumble strips several times during the ride, in both $70 \mathrm{~km} / \mathrm{h}$ and $90 / \mathrm{h}$ and if possible also brake at them. At Borensberg the riders were invited to the café. Coffee and tea was served and the interview started by the question "Please explain how you experienced driving on the rumble strips?".

The interview guide was only used when needed and it consisted of questions in the following areas: experience from driving on rumble strips, their thoughts about the aim with rumble strips (including questions about pros and cons, safety and accessibility), design of the rumble strips, acceptance and future recommendation.

The group of car commuters comprised four people, i.e., one woman and three men, 40-60 years old. They were recruited thru advertisement in the local newspaper and through personal contacts. The discussion took part in November 2007 at VTIs premises. Before the discussion started a short round the table presentation was done and information was given about the aim with the focus groups and a small presentation about the rumble strips. The discussion lasted for approximately one hour. Participants took different routes to and from work, but all drove on roads with centreline milled rumble strips during their daily commuting. Three participants were shift workers, while one travelled considerably while on duty, often late at night.

Coffee and tea was served during the event. After presenting themselves to each other the discussion started by asking the group: "What is your thoughts about rumble strips?" The interview guide was only used when needed and it consisted of in total six areas of questions: experience from first time driving on rumble strips, influence of rumble strips on their driving behaviour, $2+1$ road with barrier compared to rumble strips, acceptance among drivers, the design of the rumble strips and future recommendation. 


\subsubsection{Road-side interviews}

To have a more generic view of the drivers' opinions in close relation to their experience of driving on rumble strips a total of 360 questionnaire interviews were administered in five geographical regions of Sweden: North $(n=77)$, Middle $(n=46)$, South East $(n=83)$, South $(n=95)$, and West $(n=59)$. The roadside questionnaires were administered along roads with centreline milled rumble strips, i.e., E18, E4, E55, County Road 184, and highways 34 and 116 . To contact passing drivers, the police stopped drivers randomly to check driving licenses and test breath alcohol levels. The site selection depended on police officer availability and on the appropriateness of stopping road users. Then drivers were asked whether they were willing to participate in the study. If they agreed, the interviewer approached the car and asked if they agree to answer a limited number of questions. The surveys were completed by the interviewer. Most drivers agreed to be interviewed; some drivers declined, usually because they had a deadline to meet. The questionnaire consisted of questions about drivers' background and experience of self-reported sleepiness (KSS) during the driver [29], speed, lateral position, feeling of safety and accessibility.

\section{Results}

\subsection{Crash evaluation}

The results of the Empirical Bayes analysis, correcting for RTM as well as the general road safety trend and changes in traffic volumes are shown in Table 2. Regarding severe crashes, the results indicate that milled centerline rumble strips reduce FSI (all crash types) by 20\% (significant) and in singlevehicle crashes by $27 \%$ (significant). No significant changes are noted in injury crashes.

The EB approach relies on standard model values (i.e., estimated crash or FSI rates) developed for Swedish conditions. Table 3 shows the standard model values as well as the observed crash and injury rates, reported separately

Table 2 Estimated traffic safety effects of milled rumble strips on rural roads with $90 \mathrm{~km} / \mathrm{h}$ including corrections for RTM. 95\% confidence intervals

\begin{tabular}{lcl}
\hline Crash Type & Injury crashes & $\begin{array}{l}\text { Fatalities and seriously } \\
\text { injured, FSI }\end{array}$ \\
\hline All crashes & $-3.5 \pm 8.9$ & $-20.3 \pm 13.2$ \\
Single vehicle crashes & $0.4 \pm 11.8$ & $-26.7 \pm 18.0$ \\
\hline
\end{tabular}

for narrow $(<8 \mathrm{~m})$ and normal-width roads $(8-10 \mathrm{~m})$ to obtain as good a match as possible to the case group. In general, the observed FSI rate is lower than the standard model value. For injury crashes, the difference between the observed rate and standard model value is small for normal-width roads, while the observed rate is lower than the standard model value for narrow roads.

\subsection{Driver experience}

\subsubsection{Focus groups}

The results of the focus group discussions indicate that rumble strips are not perceived as a problem by either motorcyclists or commuters, taking into account both traffic safety and accessibility. The participants had no objections to the design of the rumble strips or to how they influence driving, although they thought that a road design with even deeper rumble strips, for example, might be even more effective.

The participants mentioned that one's speed when passing crucially affects one's experience of the rumble strip. The motorcyclists' impression was that the rumble strips feel less pronounced when one is driving fast, for example, at 90 $100 \mathrm{~km} / \mathrm{h}$ versus $70 \mathrm{~km} / \mathrm{h}$. Two members of the group of motorcyclists said:

"The impression was greater at low speeds than high speeds, so we recommend high speeds [laughing]

..." In conclusion, the impression was less at 90 and $100 \mathrm{~km} / \mathrm{h}$ than at $70 \mathrm{~km} / \mathrm{h}$."

On the other hand, the commuters' impressions were that centreline rumble strips led to lower speeds, since they provided drivers with feedback on speed when overtaking, feedback that made drivers more aware of the situation. Another issue raised by both the motorcyclists and commuters was that the type of vehicle and tires are important for one's experience of milled rumble strips. Low-quality tires and low tread depth seemed to increase the effect of the rumble strips perceived by the motorcyclists, who also commented that motorcycles without rear shock absorbers definitely registered the effects of rumble strips more than did normal sport bikes. Despite this, the motorcyclists did not seem to be influenced at all by the rumble strips, unlike the commuters, who mentioned their influence not only on their speed but also on their lateral lane position. The commuters described how they changed their driving behaviour, for example, overtaking less often and shifting their lateral lane position to the right (i.e., increasing the distance from the centre of the road). These changes in driver behaviour can be linked to an increased road safety effect, in line with the commuters' sense that the rumble 
Table 3 Standard model values (estimated accident/FSI rates) and observed crash and injury rates for the before period

\begin{tabular}{|c|c|c|c|c|c|}
\hline \multirow[t]{2}{*}{ Road type } & \multirow[t]{2}{*}{ Crash type } & \multicolumn{2}{|c|}{ Standard model values } & \multicolumn{2}{|c|}{ Observed crash/injury rate } \\
\hline & & $\begin{array}{l}\text { Injury } \\
\text { crashes }\end{array}$ & $\begin{array}{l}\text { Fatalities and } \\
\text { seriously injured (FSI) }\end{array}$ & $\begin{array}{l}\text { Injury } \\
\text { crashes }\end{array}$ & $\begin{array}{l}\text { Fatalities and } \\
\text { seriously injured (FSI) }\end{array}$ \\
\hline Rural roads, $90 \mathrm{~km} / \mathrm{h}$ & All & 0.1220 & 0.0506 & 0.090 & 0.0359 \\
\hline Narrow roads, $<8 \mathrm{~m}$ & Single vehicle & 0.0820 & 0.0285 & 0.052 & 0.0182 \\
\hline Rural roads, $90 \mathrm{~km} / \mathrm{h}$ & All & 0.0929 & 0.0376 & 0.093 & 0.0314 \\
\hline Normal width roads, $8-10 \mathrm{~m}$ & Single vehicle & 0.0542 & 0.0166 & 0.057 & 0.0164 \\
\hline
\end{tabular}

strips were a traffic safety measure. A driver from the commuter group said:

\begin{abstract}
"I hesitate a bit more to overtake. / ... / Unless there is someone who is driving really slowly, so you just have to. You take less risk in this way. / ... / In conclusion, you take it more gently, are more careful when overtaking...."
\end{abstract}

\subsubsection{Road-side interviews}

The average age of drivers was 50 year (SD 14.7) and there was no difference in their mean age between the different geographical regions $(\mathrm{F}=1.37 ; p=0.22)$. On average, the drivers had possessed their driving licenses in 31 years (SD 14.7 years) and the majority (74\%) drove more than $15,000 \mathrm{~km}$ per year. Of the 360 respondents, $74 \%$ were male and $26 \%$ female. Most of the drivers $(83 \%)$ did not believe that they had reduced their speed because of the rumble strips, while $12.5 \%$ said that they might have reduced their speed. Most drivers (58\%) said that they had not changed their distance from the centre of the road because of the rumble strips, and $37 \%$ said that they might have increased their distance from the centre line. Most of the drivers (62\%) thought that the rumble strips would increase the feeling of security, defined in terms of "you cannot leave your lane without knowing it". There was no significant difference between males and females (X2 $=3.04 ; p=0.22)$. The most positive response to the rumble strips concerned a feeling of safety $(84 \%)$, defined as "fewer oncoming vehicles that leave their lanes without knowing it.". Also, no significant difference was seen between males and females (X2 $=4.87 ; p=0.09$. In total, $90 \%$ of the drivers believed that the rumble strips would contribute to increased traffic safety. Among 354 drivers 23 reported high levels of sleepiness (KSS 8-9) during the driver. All of them except one agreed that rumble strips would contribute to traffic safety. For those remaining 331 drivers with less degree of self-reported sleepiness 298 believed the rumble strips would contribute to traffic safety, and 20 drivers did not. The difference between the groups was not statistical significant.

\section{Discussion}

Studies of the traffic safety effects of centreline milled rumble strips in Sweden, corrected for the effect of regression to the mean, indicate a $20 \%$ reduction in the number of fatalities and seriously injured people (all crash types) and a $27 \%$ reduction in the number of fatalities and severely injured in singlevehicle crashes. It was also shown that road users, especially the motorcycle riders, were positive about the rumble strips. The interviewed experienced commuters were also positive about the rumble strips, even though they thought the strips would force them to reduce their speed and overtake other cars less often. The present questionnaire study demonstrated that $90 \%$ of the drivers report that the rumble strips would contribute to increased traffic safety.

The criteria for selecting roads for the installation of rumble strips did not include a high crash record of the road, and the results of this study indicate that the crash rates observed in the before period were lower than expected from the standard modelled values, leading us to suspect regression to the mean (RTM) effects [21]. Here we used an EB approach developed for Swedish conditions to correct for RTM. After correction for RTM effects, the present results can be compared with those of earlier studies from the USA [23], which found that injury crashes were reduced by $14 \%$ (significant) and frontal and opposing-direction sideswipe injury crashes by $25 \%$ when centreline rumble strips were installed. Estimates suggest that the number of crashes will decrease by $15 \%$ after the installation of milled rumble strips in the middle of the road [6], and a pilot study in Finland [30] estimated that personal injury crashes, head-on collisions, and running off the road to the left would be reduced by approximately $10 \%$. A metaanalysis, including different types of rumble strips, estimated that centreline rumble strips reduced head-on crashes by $24 \%$ while no significant effect was demonstrated for the total 
number of crashes [5]. The slight difference between these results, although they all tend in the same direction, might be due to different rumble strip designs. In our study, only conventional milled rumble strips were examined; it is not known what sorts of rumble strips were examined in some of the other studies. The differences in results might also depend on how and whether RTM is considered. In this study, considering RTM makes a large difference for the numbers of fatalities and seriously injured people, but for all injury accidents. Other aspects that might explain the inter-studies variability are road features and cultural differences. In the ITERATE-project where a unified model of driver behaviour was developed, it was found that country (or possibly culture) was a significant factor for almost all performance indicators [31]. However, it was not further investigated which aspects differed between drivers from different countries. It has also been shown that road width might affect the safety benefits. In an earlier study larger effects were shown for narrow roads with road width below eight meters compared to roads $8-10 \mathrm{~m}$ wide [32].

The results of our study are supported by analyses of crash scenarios based on detailed police reports from the Swedish crash data system STRADA. These analyses indicate that centreline milled rumble strips reduce the risk of multivehicle collisions and crashes in which a driver drives leftward off the road [33]. Simulator studies also demonstrate that rumble strips are effective in awakening sleepy drivers and that drivers awakened by rumble strips take the proper countermeasures [14, 17]. Most studies examine rumble strips used in the centre of 8-10-m-wide roads, though they could also be used in the centre of the lane. Pre-pilot tests have examined such a possibility, and though their results were positive, motorcyclists complained that such strips influenced and reduced their ability to follow the road as desired. Finding a solution to these problems calls for further investigation.

Another issue is that it is more and more common with invehicle Lane Departure Warning systems with the aim to reduce single vehicle and head-on crashes, and that an increasing rate of cars with LDW systems has affected the results in this study. Very positive effects of in-vehicle LDWs in single vehicle crashes $(-53 \%)$ have been show [19]. However, since the design of our study considers both a case group (roads with milled rumble strips) and a control group (roads without rumble strips), it is not likely that an increasing rate of cars equipped with LDWs has affected the results in the study.

As regards behavioural adaptation (BA), the results of the present road-side interviews of 360 car drivers indicate that most of them (83\%) did not believe that they had reduced their speed because of the rumble strips, but that if they imagined any change it would be a reduction in speed (12.5\%). In addition, $58 \%$ of the drivers said that they had not changed their distance from the centre of the road because of the rumble strips, while $37 \%$ said they might have increased their distance from the centre line where the rumble strips were installed. In conclusion, however, $90 \%$ of the drivers believed that the rumble strips would contribute to increased traffic safety. The focus group discussions indicated that motorcyclists did not believe that the rumble strips would influence their driving behaviour, except that they would contribute to their safety. In contrast, the group of commuters believed that they might lower their speed, would overtake less often, and would d shift their lateral position to the right of the road. These results are in line with measurements of speed and lateral position in traffic flow made in a pre-study [34] showing a speed reduction of $2 \mathrm{~km} / \mathrm{h}$ in average and a change in lateral position of $5 \mathrm{~cm}$ to the right (right hand traffic). In relation to in-vehicle LDW systems an evaluation whether a LDW system would induce BA was done [35]. Results showed that drivers with LDW systems tend to overreliance on such systems which might lead to less positive safety effect. However, it has also been showed that in-vehicle LDW systems improved driving performance overall [36].

Another issue not covered here is external noise. In Sweden, a buffer zone of $150 \mathrm{~m}$ from buildings is used to prevent noise nuisance. Studies of external noise find that if the general Swedish guideline values for road traffic noise would increase by $5 \mathrm{~dB}$ to $65 \mathrm{~dB}$ (outdoors) and $40 \mathrm{~dB}$ (indoors), in the same way that industrial noise are addressed, possibly resulting in limit values being exceeded at distances of under $140 \mathrm{~m}$ (outdoors) and $80 \mathrm{~m}$ (indoors) [37]. Some initiatives have used sinusoidal milled rumble strips in combination with, for example, drop-flex lane markings [38]. These initiatives aim both to protect the line markings and reduce the external noise; the results are positive, although the internal noise seems to be reduced considerably [39]. This raises the question of what really awakens and alerts drivers, the noise or the vibrations from the rumble strips. Further studies are needed to answer this question.

Comparison of conventional and sinusoidal rumble strips indicates that sinusoidal rumble strips generate lower internal noise in the car as well as less vibration compared to conventional strips at both 70 and $90 \mathrm{~km} / \mathrm{h}$. Regarding the external noise, there is no difference at $70 \mathrm{~km} / \mathrm{h}$, but external noise is somewhat lower level for sinusoidal strips at $90 \mathrm{~km} / \mathrm{h}$, in other words, a difference of $1-4 \mathrm{~dB}(\mathrm{~A})$ compared with $7 \mathrm{~dB}(\mathrm{~A})$ for conventional strips. It should be noted that these sinusoidal strips were studied using cars, and that their effects have not been studied for heavy vehicles [33].

\subsection{Limitations and future research}

Based on the present results, we strongly recommend the use of centreline milled rumble strips on two-lane rural roads, a conclusion also supported by other $[23,40]$.

However, we still need more knowledge of optimal rumble strip design in terms of driver awakening results. This study examined only conventional milled rumble strips. In several 
other studies strip design is usually not controlled for, which might partly account for some differences between their results and the present results. Other important questions are whether there are any differences in effectiveness related to the reason for lane departure, and whether there are any rumble strip designs that can awaken and alert drivers without contributing to external noise. It might be useful to develop installation guidelines covering aspects such as: in-ground profile; rumble strip width, length, and depth; and milled versus pressed and conventional versus sinusoidal rumble strips. There are also arguments against this since fundamental research has not been conducted on the stimuli levels necessary to alert impaired drivers [40].

In addition, more knowledge is needed of the effects of rumble strips for heavy vehicles. Since the results indicate that driver's positioning on the road is influenced, it is also important to study the effect of rumble strips on road surface damage in greater detail.

The method used to correct for RTM is based on an EB approach developed for Swedish conditions. This method may need updating, and further analysis and comparison of different methods to correct for RTM are a future recommendation.

Lateral positioning results indicate that rumble strips cause drivers to move away from the centre line and that the variance in lateral position may therefore decrease. From a maintaining perspective this might lead to increased rutting and wear. This matter merits further investigation.

Using the method discussion within focus groups are very useful to have a wider understanding of the drivers reasoning, at the same time it is important to understand that other individuals within driver categories that were approach might have other experiences not covered here. The questionnaires used at the road side is quantitative way of gathering data. It can be argued that the results might be biased due to the police officers' involvement with stopping. In order to avoid this, the police officers were informed beforehand of the importance of how they approached the drivers and in addition, the drivers that agreed were asked to drive some meters further were the interviewer were waiting. Either in the focus groups or in the questionnaires questions were asked about the difference between infrastructures based rumbles strips versus in-vehicle systems, or of the acceptance of the rumble strips or the experience of the internal noise they generate. In the future it might be important to learn more about the drivers' opinion about this. The focus groups aimed to get a deeper understanding of considerations about rumble strips. However, it should be kept in mind that only two groups were involved and that more groups should be used to make sure all information possible to receive was included.
In conclusion, the study provides positive results when installing centreline milled rumble strips on two-lane rural roads $8-10 \mathrm{~m}$ wide which should be taken into consideration by road authorities considering this engineering measure.

Acknowledgment The authors acknowledge the Swedish Transport Administration who funded this research, the Swedish police that stopped all drivers and the drivers that responded to the questions.

Open Access This article is distributed under the terms of the Creative Commons Attribution 4.0 International License (http:// creativecommons.org/licenses/by/4.0/), which permits unrestricted use, distribution, and reproduction in any medium, provided you give appropriate credit to the original author(s) and the source, provide a link to the Creative Commons license, and indicate if changes were made.

\section{References}

1. Russels E, Rys M (2005) Centreline rumble strips - a synthesis of highway practice. Transportation Research Board, Washington D.C

2. Torbic D, Hutton J, Bokenkroger C, Bauer K, Harwood D, Gilmore D, Dunn J, Ronchetto J, Donnell E, Sommer III H, Garvey P, Persaud B, Lyon C (2009) Guidance for the design and application of shoulder and centerline rumble strips.

3. Gårder PAJ (1994) Fatigue related accidents and continuous shoulder rumble strips. University of Maine, Orono

4. Hatfield J, Murphy S, Job R, Du W (2009) The effectiveness of audio-tactile lane-marking in reducing various types of crash: a review of evidence, template for evaluation, and preliminary findings from Australia. Accid Anal Prev 41:365-379

5. Elvik R, Hoye A, Vaa T, Sorensen M (eds) (2009) The handbook of road safety measures. Bingley Emerald Publishing, Oslo

6. Mahoney R, Porter R, Donnell D, Pietrucha M (2003) Evaluation of centerline rumble strips on lateral vehicle placement and speed on two-lane highways. Pennsylvania Department of Transportation, Harrisburg

7. Persaud B, Retting R, Lyon C (2003) Crash reduction following installation of Centreline rumble strips on rural two-lane roads. Ryerson University, Toronto, Canada

8. Gårder P, Davies M (2006) Safety effects on Continously shoulder rumble strips on rural interstates in Maine. J Transp Res Board 1953:156-162

9. Meuleners L, Hendrie D, Lee A (2011) Effectiveness of sealed shoulders and audible edge lines in Western Australia. Traffic Injury Prevention 12(2):201-205

10. Smith E, Ivan J (2005) Evaluation of safety benefits and potential crash migration due to Shcoulder rumble strips installation on Connecticut freeways. J Transp Res Board 1908:104-113

11. Phillips R, Sagberg F (2010) Woken by rumble strips. Reports from drivers who have fallen asleep at the wheel. TØI report 1094/2010. Institute of Transport Economics, Oslo

12. Miles JD, Pratt MP, Carlson PJ (2006) Evaluation of erratic maneuvers associated with Installateion of rumble strips. J Transp Res Board 1973:73-79

13. Noyce D, Elango V (2004) Safety evaluation of centerline rumble strips. J Transp Res Board 1862:44-53

14. Anund A, Kecklund G, Vadeby A, Hjalmdahl M, Akerstedt T (2008) The alerting effect of hitting a rumble strip-a simulator study with sleepy drivers. Accid Anal Prev 40(6):1970-1976. doi:10. 1016/j.aap.2008.08.017

15. Räsänen M (2005) Effects of a rumble strip barrier line on lane keeping in a curve. Accid Anal Prev 37:575-581 
16. Pratt M, Miles J, Carlson P (2006) Evaluation of operational impacts of installation of centerline and edge line rumble strips. $\mathrm{J}$ Transp Res Board 1973:80-88

17. Anund A, Ahlström C, Kecklund G, Åkerstedt T (2011) Rumble strips in centre of the lane and the effect on sleepy drivers. Ind Health 49(5):549-558. doi:10.2486/indhealth.MS1247

18. Anund A, Kircher A, Tapani A (2009) The effect of milled rumble strips versus virtual rumble strips on sleepy drivers: a driving simulator study. Linköping

19. Sternlund S, Strandroth J, Rizzi M, Lie A, Tingvall C (2016) The effectiveness of lane departure warning systems - a reduction in real-world passenger car injury crashes. Traffic Inj Prev. doi:10. 1080/15389588.2016.1230672

20. Lehmann L (2001) Elements of large-sample theory. Springer, New York

21. Hauer E (ed) (1997) Observational before-after studies in road safety. Estimating the effect of highway and traffic engineering measures on road safety. Pergamon, Oxford, UK

22. Elvik R (2008) The predictive validity of empirical Bayes estimates of road safety. Accid Anal Prev 40:1964-1969

23. Persaud B, Retting R, Lyon C (2004) Crash reduction following installation of Centreline rumble strips on rural two-lane roads. Accid Anal Prev 36:1073-1079

24. Brüde U, Larsson J (1988) The use of prediction models for eliminating effects due to regression-to-the-mean in road accident data. Accid Anal Prev 20(4):299-310

25. Administration ST (2014) Effektsamband för transportsystemet Bygga om eller bygga nytt - version 2014-04-01. Borlänge

26. Kreuger R (1994) Focus groups: a practical guide for applied research, 2nd edn. Sage, Thousand Oaks

27. Morgan D, Krueger R (1998) The focus group kit. Sage Publications Inc, Thousand Oaks, USA

28. Anund A, Nyberg J (2009) Trafikanternas uppfattning om frästa räfflor i mitten på 2-fältsväg. Fokusgrupper med motorcyklister och pendlare samt vägkantsintervjuer Statens Väg och Transportforsknings institut, Linköping

29. Åkerstedt T, Gillberg M (1990) Subjective and objective sleepiness in the active individual. Int J Neurosi 52:29-37

30. Rajamäki R (2010) Räfflade vägmarkeringars effekt på trafiksäkerheten. Helsingfors

31. Peters B, Vadeby A, Forsman Å, Tapani A (2012) Developing a unified model of driving behaviour for cars and trains. Shaker, Leeds

32. Vadeby A, Björketun U (2016) Safe accessibility - traffic safety evaluation 2013 and 2014 VTI report.

33. Vadeby A, Anund A, Björketun U, Carlsson A (2013) Safe accessibility, summarized results. Linköping

34. Anund A (2005) Frästa räfflor i mitten på tvåfältsväg. Linköping, Sweden

35. Rudin-Brown C, Noy Y (2002) Investigation of behavioral adaptation to lane departure warnings. J Transp Res Board 1803(1):30-37. doi:10.3141/1803-05

36. Jordan N, Yousfi E, Deniel J, Jallais C, Bueno M, Alexandra F (2016) The impact of false warnings on partial and full lane departure warnings effectiveness and acceptance in car driving. Ergonomics 59:1-30. doi:10.1080/00140139.2016.1158323

37. Ögren M (2013) External noise from milled centerline rumble strips. Linköping

38. Engen T, Giaever T, Haukland F (2011) Forsterket midtoppmerking: forsok med rumleriller i ovre Bekerud. SINTEF Teknologi og samfunn, Trondheim

39. Giaever T, Engen T, Hauakkland F (2010) Evaluering av forsterket midtoppmarkering i Hedmark, Oppland. SINTEF, Trondheim

40. Torbic D, Hutton J, Bokenkroger C, Bauer K, Donnell E, Lyon C, Persaud B (2010) Guidance on design on application of rumble strips. J Transp Res Board 2149:59-69 